\title{
FOOD AND FEEDING OF FISHES. WHAT DO WE NEED TO KNOW?
}

\author{
Surjya Kumar SAIKIA * \\ * Aquatic Ecology and Fish Biology Laboratory, Department of Zoology, Visva Bharati University, \\ Santiniketan, West Bengal, India, IN-731235, surjyasurjya@gmail.com
}

DOI: 10.1515/trser-2015-0049

KEYWORDS: feeding ecology, ecomorphology, chemoecology, food selection.

\section{ABSTRACT}

Unrevealing food and feeding habits of fishes is the centre of research in aquatic biology, ecology, conservation biology and fisheries. The current practice in feeding ecology of fish accredits it as descriptive ecology, relying primarily on the information of their diet, directly through gut analysis or indirectly by computing some diet based indices. Such methods often mislead in the understanding of the true feeding behaviour of organisms need for more reliable and functional approach. The main objective of feeding ecology is to evaluate feeding behaviour of fish. Recent developments in tools and techniques of analytical research is an opportunity to take up more reliable details by formulating affordable methodical design for recording, modulating and designing suitable approaches for better explanation of the feeding biology in fish. wissen?

ZUSAMMENFASSUNG: Nahrung und Ernährungsart der Fische. Was müssen wir

Das Auffinden der Nahrung und die Ernährungsart der Fische steht im Mittelpunkt der Forschungen zur aquatischen Biologie, Ökologie und Erhaltung der biologischen Vielfalt sowie der Fischereibetriebe. Gegenwärtig ist die Ernährungsökologie der Fische Teil der deskriptiven Ökologie, die sich unmittelbar auf Informationen der Nahrungsanalyse des Mageninhaltes oder indirekt auf die Berechnung einiger Nahrungsindikatoren stützt. Derartige Methoden erzeugen Verwechslungen hinsichtlich des Ernährungsverhaltens und erfordern eine umfassende Neubearbeitung für eine sichere und funktionelle Herangehensweise. Das Hauptziel der Ernährungsökologie ist die Auswertung des Verhaltens der Fische während der Nahrungsaufnahme. Die Verbesserung der Apparatur und der analytischen Untersuchungstechniken ermöglicht eine genauere Analyse mittels einer zugänglichen Formulierung eines Designs für die Registrierung, Vorbereitung und entsprechende Herangehensweise zur genaueren Erklärung der Ernährungsbiologie der Fische.

REZUMAT: Hrana și modul de hrănire al peștilor. Ce trebuie să știm?

Descoperirea hranei și a modului de hrănire al peștilor este centrul cercetării pentru biologia acvatică, ecologie, biologia conservării și pentru fermele piscicole. La momentul actual ecologia hrănirii peștilor este parte a ecologiei descriptive, bazându-se în principal pe informația dietei primită direct din analiza conținutului stomacal sau indirect prin calcularea unor indici de dietă. Astfel de metode creează confuzie în înțelegerea exactă a comportamentului de hrănire și necesită o revizie extensivă pentru o abordare sigură și funcțională. Obiectivul principal al ecologiei hrănirii este evaluarea comportamentului de hrănire al peștilor. Perfecționarea instrumentelor și tehnicilor de cercetare analitică permite o analiză mai precisă prin formularea accesibilă a unui design pentru înregistrarea, ajustarea şi conceperea unor abordări adecvate pentru explicarea mai exactă a biologiei hrănirii peștilor. 


\section{INTRODUCTION}

Examining the food and feeding habits of a species is important for evaluating the ecological role and position of the species in the food web of ecosystems (Allan and Castillo, 2007). Information on their diet provides further support on practices of aquatic management, especially agriculture, aquaculture and conservation. Among many animals in aquatic ecosystem, fish are a major top predator and occupy a deterministic status in the trophic cascade of the aquatic ecosystem. Several species of fishes play an important role in economies in many countries around the world. However, what determines the success in commercialization of fish is the food it receives for growth and nutrition. There are several types of formulated and commercially available feed for fish. However, the basis of formulation of such artificial feed mainly targets protein supplementation and hardly fulfils all nutritional requirements including micro-nutrients, thereby, replacing other essential nutrients from fish food. Similarly, introducing non-native fish species for higher economic gain is common among developed and developing countries. These practices often threaten native fish species towards extinction. A crucial factor to the native fish species encountering the introduction of a non-native fish is the overlapping of trophic niches (Olden et al., 2006). Avoidance of competition for food or management of niche partitioning may lead to successful co-habitation of the species (Curtean-Bănăduc A. and Bănăduc D., 2008).

The question is: could it be possible to gather accurate and real scientific information on the food and feeding habits of fish? There are several challenges that need to be addressed. A few of them are:

1. Fish explore high habitat diversity expanding from marine to freshwater; morphological diversity from the smallest to the largest in body size; behavioural diversity of the inhabitant to migratory in nature, etc.

2. It passes through several ontogenic stages during its development and each stage may prefer different types of food and exhibit variable feeding habits.

3. Several fishes exhibit opportunistic feeding behaviour, i.e. they may shift their feeding habit between two isomorphic food habitats. For example, the omnivorous fish Cyprinus carpio and herbivorous fish Labeo rohita, and hybrid Oreochromis aureus $x$ Oreochromis niloticus, may shift to periphytophagus mode of feeding when substrates are available in the environment (Milstein et al., 2013; Saikia and Das, 2009; Saikia et al., 2013).

The subject has been discussed over time with different approaches to obtain meaningful conclusions on the feeding habit of fish. For all these reasons, the generalization of food and feeding habits in fish, in reality, is a very arduous task. The main purposes of this paper, on the above background, is: (a) to highlight gaps in current knowledge on their feeding biology and demonstration of possible approaches to overcome those gaps; (b) to summarize different approaches to describe and enumerate food and feeding habits in fish effectively.

\section{The bottlenecks}

There are two broad topics traditionally addressed while discussing feeding habits of animals. These are: (i) diet that comprises of the food habitually eaten by the animal; (ii) the mode of feeding or ingesting diet in a particular spatio-temporal dimension.

In fishes, two methods are available to find the above criteria. First, the assessment of stomach content using various descriptive mathematical techniques. Stomach content has long been used for preliminary assessment of diet in aquatic animals (Cortés, 1997; Ellis et al., 1996). In fish with a stomach, the stomach is dissected and undigested food or food particles are recorded qualitatively and quantitatively (Baker et al., 2014; Pelicice and Agostinho, 2006). There exists a handful tools of which can be used to estimate the stomach contents in 
the fish (Tab. 1). When a true stomach is not available, food from the first few portions of the gut is collected for analyzing. Second, all data recorded is subjected to mathematical models proposed by different authors (Tab. 2). Some of these models, for example Levin's diet breadth, Ivlev's electivity index, Hulberts index, etc., are popularly used irrespective of fish species. Figure 1 describes how the feeding habits of fish are being studied by different authors following these models. Two key words, "feeding habit" and "feeding ecology" were used to gather random web-based information through "Google" for collection of data $(N=70)$ in figure 1 . Large numbers of studies are performed using percentage abundance data.

Table 1: Different measures used to estimate stomach content of fish. Examples are stated randomly.

\begin{tabular}{|c|c|c|}
\hline $\begin{array}{c}\text { Crt. } \\
\text { no. }\end{array}$ & Description of index & Author for reference \\
\hline 1. & (Prey item recorded/total wet weight of food) $\times 100$ & e.g. Pothoven and Nalepa, 2006 \\
\hline 2. & Visual inspection $(0.25,0.50,0.75$ and 100$)$ & e.g. Pelicice and Agostinho, 2006 \\
\hline 3. & Vacuity coefficient & e.g. Figueiredo et al., 2005 \\
\hline 4. & Frequency of occurrences & e.g. Hajisamae et al., 2003 \\
\hline 5. & Volumetric contribution & e.g. Hajisamae et al., 2003 \\
\hline 6. & (Total stomach content weight/fish weight) $\times 100$ & e.g. Hyslop, 1980 \\
\hline 7. & Weighted resultant index & Mohan and Sankaran, 1988 \\
\hline 8. & Index of Relative Importance & Pinkas et al., 1971 \\
\hline 9. & Index of Preponderance & Marshall and Elliot, 1997 \\
\hline 10. & Feeding index & Kawakami and Vazzoler, 1980 \\
\hline
\end{tabular}

Table 2: Mathematical models for diet analysis in fish.

\begin{tabular}{|c|c|c|}
\hline $\begin{array}{c}\text { Crt. } \\
\text { no. }\end{array}$ & Description of index & Author for reference \\
\hline 1. & Pianka's overlap index & Pianka, 1973 \\
\hline 2. & Pelicice feeding activity index & Pelicice et al., 2005 \\
\hline 3. & Shannon index & Marshall and Elliot, 1997 \\
\hline 4. & Repletion index & e.g. Figueiredo et al., 2005 \\
\hline 5. & Electivity index & Ivlev, 1961 \\
\hline 6. & Levin's standardized index 1989 \\
\hline 7. & Schoener's overlap index & Schoener, 1970 \\
\hline 8. & Pearre's selectivity index & Pearre jr., 1982 \\
\hline 9. & Manly's $\alpha$ & Chesson, 1978 \\
\hline 10. & Saikia’s diet breadth index & Saikia, 2012 \\
\hline 11. & Hurlbert's diet breadth & Hulbert, 1978 \\
\hline 12. & Moritia’s index & Krebs, 1989 \\
\hline
\end{tabular}






Figure 1: Frequency of citations of some (a) indices to study gut content and (b) models for preference/rejection analysis in fish $(\mathrm{N}=70)$. H, Sahnnon index; E, Electivity index;

V, Vacuity index; FO, Frequency of Occurrence; WI, Weighted resultant index; IP, Index of preponderance; IRI, Index of relative importance.

Although, stomach/gut content analysis fulfils the primary objective to enlisting the common foods that find passage to the alimentary canal of the fish, their computation using defined models may often have biased results and erroneous outcomes. The following observations are generally ignored: (i) Stomach/gut content analysis solely depends on the available undigested food present in the stomach/gut of the fish at the time of sampling. It gives just a "snapshot" to the food content in the gut at a particular time. An empty gut, however, does not always indicate that the fish avoids the food available in its surroundings. The cause of such avoidance of food in a particular moment by fish may be environmental e.g. insufficient temperature to support metabolic rates in the gut of the fish. In Sockeye Salmon Oncorhynchus ranka, rate of digestion is reported to be highly dependent on temperature (Brett and Higgs, 2011). There may be several other external factors (e.g. pH, salinity, turbidity, conductivity, etc.), influencing the acceptance and rejection of a particular diet by fish. 
(ii) The general practice of identification and quantification of gut content in fishes mostly addresses undigested parts of the ingested diet. In the case of plankton feeders, soft bodied zooplankton (e.g. protozoa, some rotifers) are often skipped off the counting procedure for their rapid digestibility. There is a clear differentiation of the enzymatic activity among fishes from different trophic status as well as food habits. For example, herbivorous and omnivorous species have been reported to have more amylase activity than carnivorous species (Fish, 1960; Sabapathy and Teo, 1993; Vonk and Western, 1984). Thus, it is obvious that some food items from the gut in those fishes would be missed resulting in variation of their quantitative data on food. Another physiological factor is the gut retention time that may, directly or indirectly, influence enzyme activity on the digestion of the food. Information from the gut contents is, therefore, biased and never gives reliable basis for generalization on the feeding habit of fish.

(iii) Subsequently to gut content analysis, different normalized models are used to enumerate a clearer picture of the feeding habit of fish. Table 2 gives the summary of some of such mathematical models. The feature that is uniform to all these models is that these are based on the presence/absence matrix of food in the gut content. Although these models give enough statistical background on the feeding habit of fish, it is not possible to draw a conclusion on feeding the biology of fish because of highly biased presence/absence matrix. Cellular counts like colonial algae (e.g. Secenedesmus sp, Navicula sp., etc.) often dominate biomass counts like zooplankton (e.g. Daphnia sp., rotifers, etc.). Moreover, biomass counts are less prevalent and more erroneous. In addition, a precision to sample size is not available to describe what amount of sample is to be collected to precisely document the diet in fish. Lack of uniformity while using these models for diet analysis is another limitation to draw a comparative conclusion on the diet of different fish. Figure 1 shows how variably these models are used in 70 research articles to describe the food habits of fish.

(iv) The lack of expediency in the currently practiced methods becomes clear when biological features of fish are correlated with food habits. Studies on fishes where diatoms were found to be highly preferred among planktonic food lack information on the respective biological features favouring such food (e.g. Magana, 2009; Sherwood and Nishimoto, 2005). In some cases, change in the feeding habit with ontogeny (juvenile to adult) is not discussed in relation to the change in the biology of the fish (e.g. Brandão-Gonçalves and Sebastien, 2013; OforiDanson and Grace, 2006). The important part is the feeding habit without any true interpretation to biological features of the organism is always incomplete.

All the above problems are very basic studies in the feeding biology of fish and need attention in order to understand the realistic mechanisms involved in food preference and biology of the fish. The following part of this article makes an effort to underline some methodical approach to overcome these problems.

\section{Feeding Ecology}

The overall study on the food and feeding habits of animals can be discussed under the term "Feeding Ecology". It defines a relationship where the animal adopts a strategy for optimum foraging of predation on its preferred food. The broad domains of feeding ecology are described below (Fig. 2): an informative account of food organisms naturally ingested by the fish; quantification of gut content; morphological adjustment in the mouth or any other body morphs of the fish in relation to the food it ingests; organic environment in the gut; olfaction for reception and rejection of food; molecular signalling of food reception. 


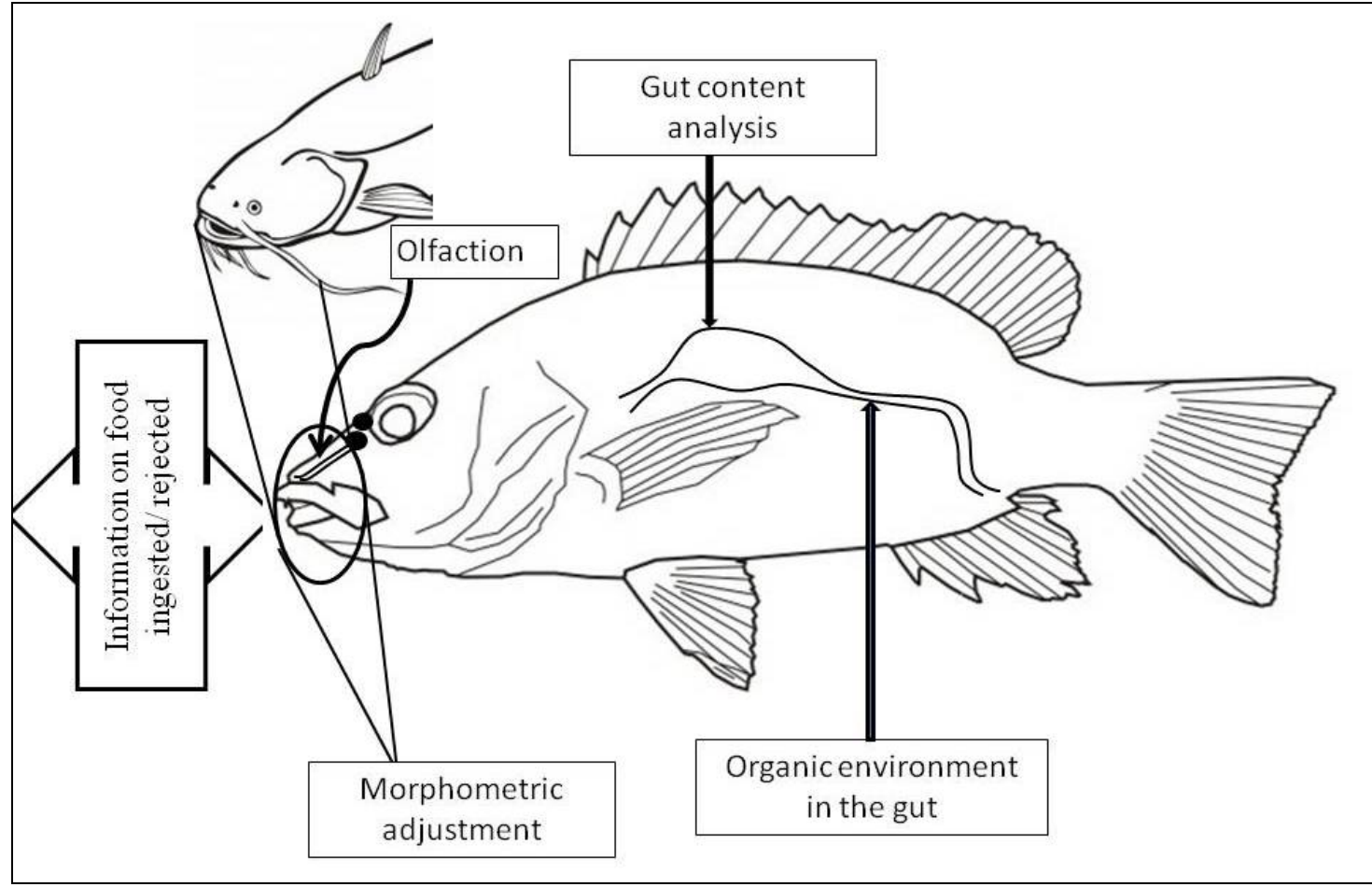

Figure 2: Domains needed to describe feeding ecology in fish.

\section{Methods to Study Feeding Ecology in fish \\ Stomach or gut content}

Stomach or gut content analysis is indeed the first part of feeding ecology, and could be met sufficiently by following the methods described in Hyslop (1980). From the stomach of bearing fishes, food may be collected from both oesophagus and stomach, as in most cases, soft bodied food remained intact in oesophageal part. However, in the case of stomachless fishes, a good practice comprises of dissecting the whole stomach since some hard bodied food may occur in the distal part of the fish.

\section{Quantification of food and feeding ability}

Frequency data (relative abundance or relative occurrence) from gut samples are used to analyse food selection, and weight or volumetric data (gut fullness) are used to estimate feeding intensity relationships. Although, there are good numbers of methods to quantify food availability and food selection in fish (Tab. 2), all these, more or less, rely on the frequency of the occurrence of food in gut or between gut and environment. For food selection, frequency data can be used only if food resources are sampled from the environment when fish are collected. This leads to difficulty in analysis since sampling of fish and resources are not uniform and obtaining unbiased samples of food resources available for fish is, therefore, a challenge. It becomes more difficult for carnivorous fishes which feed on active preys that eventually skip during sampling. These methods, therefore, can be used to generate preliminary information on the food preference of fish. A conservative approach would be to sample in large quantities to avoid a sampling error. With some limitations, radiotracer methods are often used as more descriptive methods to enhance accuracy in results. Aihara et al. (2008) used fluorescent dye to label food using DilC $_{12}$, in order to trace the food in the gastrointestinal tract. 


\section{Ecomorphology}

As seen in the above sections, relying on only gut content data using mathematical models could lead to erroneous outcomes. According to the hypothesis in ecomorphology, diet should be predictable from the morphology of the fish, particularly from morphological traits related to feeding such as mouth size, jaw shape and dentition (Ogunlaru et al., 1997). Thereby, it aims to establish a correlation between one or several morphological features, which would indicate a potential adaptation of a particular species to a certain ecological niche (Costa and Cataudella, 2007; Teixeira and Bennemann, 2007). Thus, one may determine which environmental or biological factors are influencing individual forms within an ecosystem, thereby increasing their success in the exploitation of the available resources (Cunico and Agostinho, 2006; Motta and Kotrschal, 1992). Fish explore almost all ecological zones of aquatic ecosystem and shows high degree of variations in their mouth morphometry. Depth wise, the change in their morphometry has been outlined in figure 3. Such morphometry directly influences their feeding, especially the size-dependent selection of prey in the environment. Ecomorphology, therefore, is an appropriate term for describing the feeding ecology of a species, including food preferences, diet overlap, and habitat use.

There are different ways to study the morphology of fish. The traditional practice is to measure morphometric characters on a "longitudinal scale", recording the depth and breath. Although it is a highly prevalent practice, repeated measures on such longitudinal scale could be biased and may leave high rate of instrumental errors. Besides, the head surface of a fish is very uneven, and orientation of some parts (e.g. eyes, operculum, etc.) may vary immensly. An approach to a geometric morphometry could be more reliable over such a "meristic" approach. An easily approachable geometric technique is the TRUSS analysis. It is one of the highest recommendable techniques for morphometric characterization in fish (Strauss and Bookstein, 1982). The TRUSS allows us to take uniform landmarks for all comparable morphs of organisms on a geometric plane.

The external morphology could be further extended to internal mouth morphology of the fish. This is often seen more informative than external morphology to demonstrate feeding habit since a direct correlation exists between gustation and ability to detect chemicals through different extra- and intra-oral structures in the mouth of vertebrates. Cave dwelling fishes, with a habit to feed in the dark can be best differentiated from open water fishes feeding under light by the presence of their abundant taste buds in the mouth (Ohkubo et al., 2005). The presence of diversified taste buds on their mouth region indicates the strength of gustatory sensuality in detecting food or feeding areas by fish (Fig. 4). For example, from fishes, three types of taste buds are reported. These are Taste bud I, Taste bud II and Taste bud III. Morphologically, Type I taste buds are generally sunk in somewhat relative to the level of the neighbouring epithelial cells and mostly located near the entrance of the mouth. Type II taste buds are slightly elevated from the epithelium and not surrounded by a rill into which the base is sunk. Type III taste buds never raise above the normal level of the surface epithelium. They may be useful for ensuring full utilization of the gustatory ability of the fish, detection and analysing the quality and palatability of food, during its retention in the mouth (Elsheikh et al., 2012). In some cases, taste buds in gill rakers also supply information on the feeding habit of fish (Elsheikh, 2012). Besides, it is possible to classify fish on the basis of the gustatory reception to some specified chemical substances. 


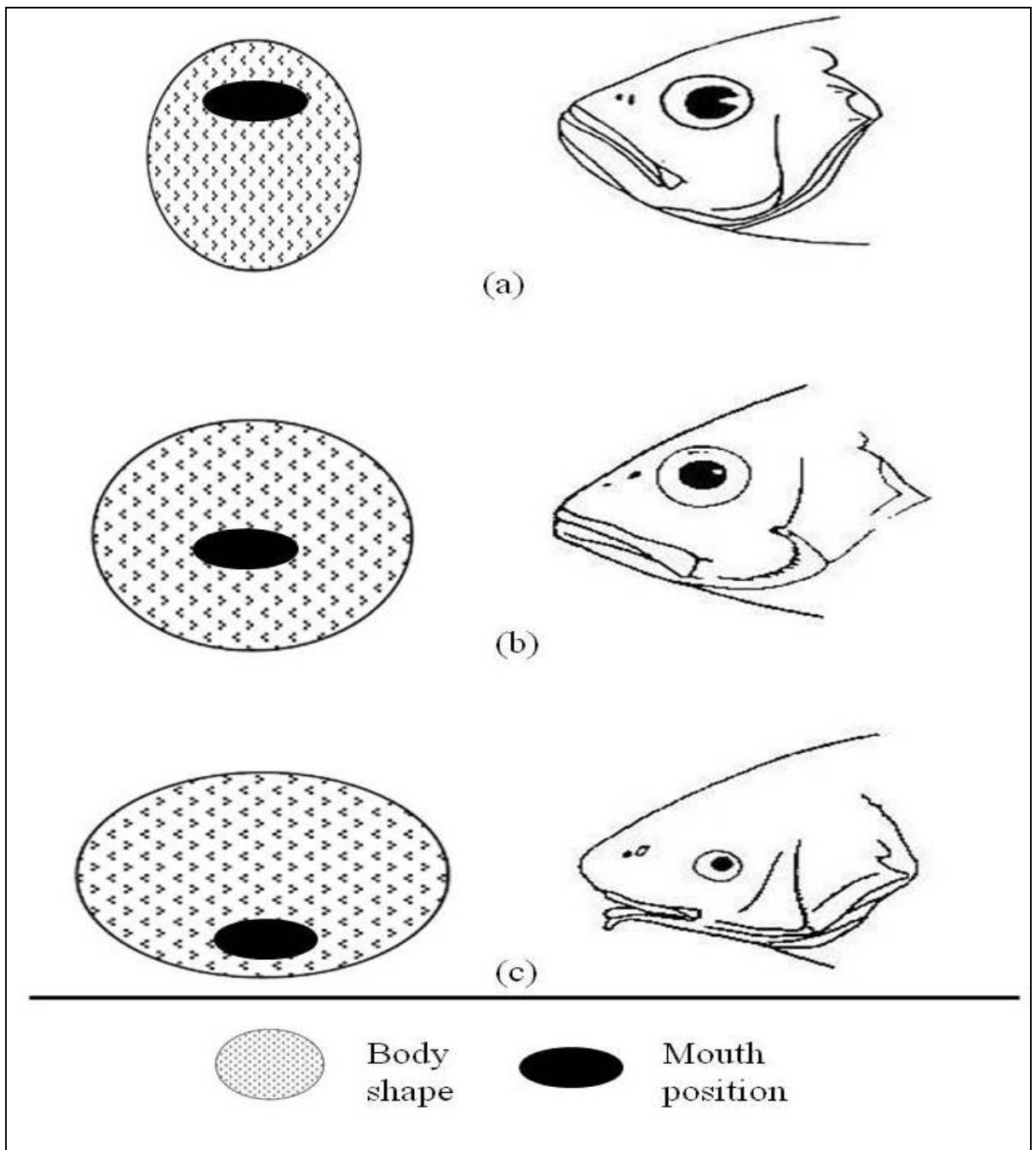

Figure 3: A general representation of ecomorphology where changes in the mouth position and body shape in fish is shown according to different depths.

(a) Surface dwellers, (b) mid-column dwellers and (c) bottom dwellers.

\section{Microbial gut flora and food}

Probiotics has become a new addition in the aquaculture research to reveal possible resident gut microflora of fish respective to the food supplement. However, studies on feeding habits still need to link food and gut microflora in their methods. Separate studies have shown that these microflora respond to digestive physiology (Cahill, 1990) and feeding strategy of fish. Ringø et al. (1995) suggested that Bacteroides sps. and Clostridium sps. enhance nutrition by providing essential fatty acids and vitamins. Some gut bacteria (e.g. phytase producing bacteria) have a high presence in carps that feed on plant or products (Khan and Ghosh, 2013; Roy et al., 2009). Their observation suggested that microbial community in the gut changes along with the ontogeny of fish (Luczkovich and Stellwag, 1993). Thus, in studies of feeding habits, a correlative analysis must be conducted to support how gut microflora assist in the digestion of ingested food. Such attempts will validate the physiology of the food digestion and absorption and help in tracing the transient foods that the fish ingests. 


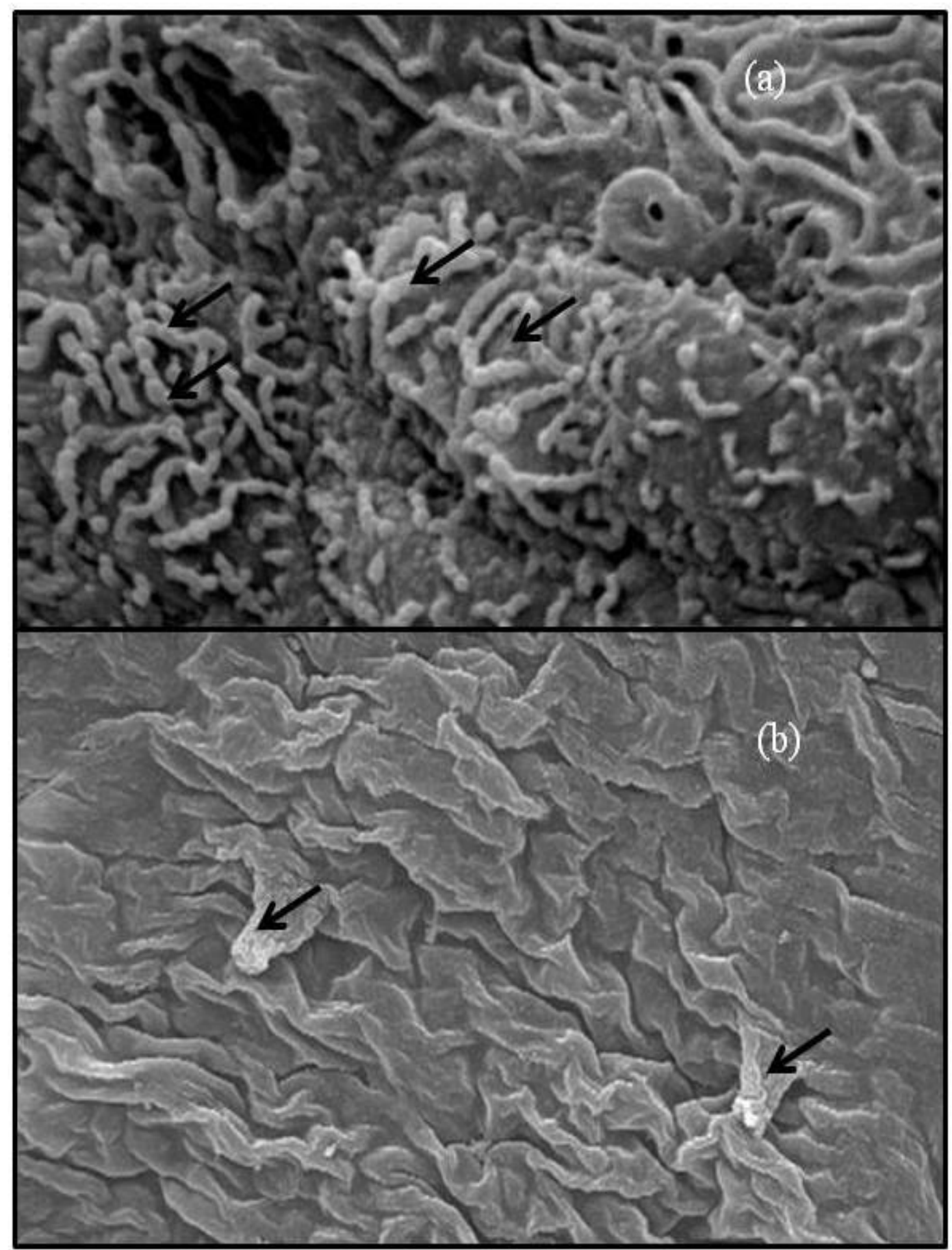

Figure 4: Scanning Electron Micrographs (SEM) on (a) bacterial association and (b) taste buds (black arrow) in the mouth region (intra-oral) of a small freshwater fish Amblypharyngodon mola. 


\section{Olfaction}

Olfaction is directly correlated to the odorant nature of substances. Food selection in fish is highly regulated by the biochemical quality of the food (Kasumyan and Morsi, 1996; Kasumyan and Sidorov, 2010; Mikhailova and Kasumyan, 2010). Primarily, a classification of fishes into three broad trophic groups as herbivorous, carnivorous and omnivorous does not indicate any precise food preferences with specific biochemical nature. There may be different amino acids or other biochemical substances stimulating olfactory receptors in fish and qualify as better food. The larvae and adults in fishes always have different choices for food based on chemical signals (Kasumyan, 2011). Fishes are often attracted towards certain chemicals available in their food and characterizing these chemicals is necessary to understand their response to desired food. It was reported that fishes are attracted towards L-Lysine and L-Arginine if available in their surroundings. The free amino acids as extracts of food odour result in high sensitivity in selecting particular type of food by fish. This is necessary to identify to which group of biochemical composites the fish may have desired attractability. The behavioural testing of fish employing the food pellet with and without the chosen chemical is the commonly adopted technique to study preferences of food based on the biochemical nature of food. There are two suggestive approaches for such behavioural tests. First, studying the frequency of touching and grasping of pellets made of taste substances computing "index of taste attractiveness" (Kasumyan and Morsi, 1996). Second, use of radiolabelled dye with taste substances and observations under a microscope (Aihara et al., 2008). However, the second approach may be followed as a confirmatory test to the first approach.

\section{Molecular Signalling}

It is obvious that reception of food through olfaction is mediated by some chemical pathways in the body. The molecular science of taste had its beginning in the late 20th century. Today great efforts have been forwarded to understand molecular biology of taste science in accordance to modern advances of tools and techniques in molecular and cell biology. For the first time, Buck and Axel (1991) identified G-protein coupled receptors as odorant receptors with seven-membrane topology and for this discovery they received the Nobel Prize of Medicine and Physiology in 2004. Since then, series of research have been initiated to study taste science in relation to food science and agriculture.

For taste reception, vertebrates in general express two families of G-protein coupled receptors (GPCRs), viz. T1Rs and T2Rs, residing on the surface of sensory cells of each taste bud (Adler et al., 2000; Hoon et al., 1999). In mammals, heteromeric T1R1/3 receptors respond to umami tastants such as amino acids (Zhao et al., 2003) whereas, T1R2/3 responds to sweet tastants like sugars or sweet proteins, etc. (Nakajima et al., 2006; Nelson et al., 2001) and T2R series of taste receptors respond to bitterness (Chandrasekhar et al., 2000). Keiko Abe and his group initiated several experiments on zebra fish (Danio rerio) and Medeka (Oryzias latipes). They observed that T1Rs and T2Rs of mammals and fish have a high degree of similarities (Abe, 2008). However, in fish, T1R2/3 heteromeric receptors form responds to amino acid rather than to sugar.

Thus, a detail on the molecular biology of taste receptors and their signalling cascade to neurosensory system has to be addressed to understand the true feeding biology of fish. 


\section{CONCLUSIONS}

Food scientists and technologists have long paid great attention for better management of food industry. Although limited, fishery industry may also participate in such efforts by developing precisely designed target oriented fish feeding module. From a habitat management point of view, there are possibilities that a change in environmental quality from protein rich sources to sugar rich sources or vice versa, or any other aversive tastes, may directly affect natural fish population in an aquatic ecosystem.

A "food based conservation" approach is highly preferred when eco-restoration deals with fish communities. It seems extremely obvious now not to rely on abstract sampling procedures for merely descriptive assessment of food and feeding biology in fish. Food science is an applied science and the detailed feeding biology of fish can contribute to formulate feeding design for better management and growth of fish. Along with animal biologists, especially those working with fish, aquatic ecologists and molecular biologists may form an integrative approach for better outlining such feeding studies.

\section{ACKNOWLEDGEMENTS}

The authors wish to thank to Miss Sudarshana Nandi, Research Associate for supplying SEM of Amblypharyngodon mola. 


\section{REFERENCES}

1. Abe K., 2008 - Studies on taste: Molecular biology and food science, Bioscience Biotechnology Biochemistry, 72, 7, 1647-1656.

2. Adler E., Hoon M. A., Mueller K. L., Chandrasekhar J., Ryba N. J. P. and Zuker C. S., 2000 A novel family of mammalian taste receptors, Cell, 100, 693-702.

3. Aihara Y., Yasuoka A., Iwamoto S., Yoshida Y., Misaka T. and Abe K., 2008 - Construction of a taste blind medeka fish and quantitative assay of its preference-aversion behaviour, Genes, Brain and Behavior, 7, 924-932.

4. Allan J. D. and Castillo M. M., 2007 - Stream Ecology: structure and function of runing waters, 2nd edition, Springer, 372.

5. Baker R., Buckland A. and Sheaves M., 2014 - Fish gut content analysis: robust measure of diet composition, Fish and Fisheries, 15, 170-177.

6. Bănăduc A. and Bănăduc B., 2008 - Trophic elements regarding the non-indigenous Pseudorasbora parva (Schlegel) 1842 fish species spreading success - Olt River basin, a case study, Journal of Bioloy - Zoology, 6, 185-196.

7. Brandão-Gonçalves L. and Sebastien N. Y., 2013 - Feeding activity and influence of intraspecific competition on zooplankton communities by jundiá (Rhamdia quelen Quoy and Gaimard, 1824) in laboratory, Brazilian Journal of Biology, 73, 4, 765-773.

8. Brett J. R. and Higgs D. A., 2011- Effect of Temperature on the Rate of Gastric Digestion in Finger ling Sockeye Salmon, Oncorhynchus nerka, Journal of the Fisheries Research Board of Canada, 1970, 27, 10, 1767-1779.

9. Buck L. and Axel R., 1991 - A novel multigene family may encode odorant receptors: a molecular basis for odor recognition, Cell, 65, 175-187.

10. Cahill M. M., 1990 - Bacterial flora of fishes: a review, Microbial Ecology, 19, 21-41.

11. Chandrasekhar J., Mueller K. L., Hoon M. A., Adler E., Feng L., Guo W., Zuker C. S. and Ryba N. J. P., 2000 - T2Rs function as bitter taste receptors, Cell, 100, 703-711.

12. Chesson J., 1978 - Measuring preferences in selective predation, Ecology, 59, 211-215.

13. Cortés E., 1997 - A critical review of methods of studying fish feeding based on analysis of stomach contents: application to elasmobranch fishes, Canadian Journal of Fisheries and Aquatic Sciences, 54, 726-738.

14. Costa C. and Cataudella S., 2007 - Relationship between shape and trophic ecology of selected species of Sparids of the Caprolace coastal lagoon (Central Tyrrhenian sea), Environmental Biology of Fishes, 78, 115-123.

15. Cunico A. M. and Agostinho A. A., 2006 - Morphological patterns of fish and their relationships with reservoirs (reservoir) hydrodynamics, Brazilian Archives of Biology and Technology, 49, 125-134.

16. Elsheikh E. H., 2013 - Scanning electron microscopic studies of gill arches and rakers in relation to feeding habits of some fresh water fishes, The Journal of Basic and Applied Zoology, 66, 121-130.

17. Ellis J. R., Pawson M. G. and Shackley S. E., 1996 - The comparative feeding ecology of six species of shark and four species of ray (Elasmobranchii) in the north-east Atlantic, Journal of the Marine Biological Association, UK, 76, 89-106.

18. Elsheikh E. H., Nasr E. S. and Gamal A. M., 2012 - Ultrastructure and distribution of the taste buds in the buccal cavity in relation to the food and feeding habit of a herbivorous fish: Oreochromis niloticus, Tissue and Cell, 44, 164-169.

19. Figueiredo M., Morato T., Barreiros J. P., Alfonso P. and Santos R. S., 2005 - Feeding ecology of the white seabram, Diplodus sargus, and the ball wrasse, Labrus bergylta, in the Azores, Fisheries Research, 75, 107-119.

20. Fish G. R., 1960 - The comparative activity of some digestive enzymes in the alimentary canal of Tilapia and Perch, Hydrobiologia, 15, 161-178. 
21. Hajisamae S., Chou L. M. and Ibrahim S., 2003 - Feeding habits and trophic organization of the fish community in shallow waters of an impacted tropical habitat, Estuarine, Coastal and Shelf Science, 58, 89-98.

22. Hoon M. A., Adler E., Lindemeir J., Battery J. F., Ryba N. J. P. and Zuker C. S., 1999 Putative mammalian taste receptors, Cell, 96, 541-551.

23. Hulbert S. H., 1978 - The measurement of niche overlap and some relatives, Ecology, 59, 6777.

24. Hyslop E. J., 1980 - Stomach contents analysis - a review of methods and their application, Journal of Fish Biology, 17, 411-429.

25. Ivlev V. S., 1961 - Experimental ecology of the feeding of fishes, Yale University Press, New Haven, Conn.

26. Kasumyan A. O., 2011 - Functional development of chemosensory system in the fish ontogeny, Russian Journal of Developmental Biology, 42, 3, 173-179.

27. Kasumyan A. O. and Morsi A. M. K., 1996 - Taste sensitivity of Common carp Cyprinus carpio to free amino acids and classical taste substances, Journal of Ichthyology, 36, 5, 391403.

28. Kasumyan A. O. and Sidorov S. S., 2010 - Taste preferences and behaviour of testing gustatory qualities of food in stone loach Barbatula barbatula (Balitoridae, Cypriniformes), Journal of Ichthyology, 50, 5, 682-693.

29. Kawakami E. and Vazzoler G., 1980 - Método gráfico e estimativa de índice alimentar aplicado no estudo de alimentação de peixes, Boletim do Instituto Oceanográfico, 29, 205-207.

30. Khan A. and Ghosh K., 2013 - Evaluation of Phytase Production by Fish Gut Bacterium, Bacillus subtilis, for Processing of Ipomea aquatica Leaves as Probable Aquafeed Ingredient, Journal of Aquatic Food Product Technology, 22, 5, 508-519.

31. Krebs C. J., 1989 - Ecological Methodology, New York, Harpet and Row.

32. Luczkovich J. J. and Stellwag E. J., 1993 - Isolation of cellulolytic microbes from the intestinal tract of the pinfish Lagodon rhomboids: size related changes in diet and microbial abundances, Marine Biology, 116, 381-388.

33. Magana H. A., 2009 - Feeding Preference of the Rio Grande Silvery Minnow (Hybognathus amarus), Reviews in Fisheries Science, 17, 4, 468-477.

34. Marshall S. and Elliot M., 1997 - A comparison of univariate and multivariate numerical and graphical techniques for determining inter- and intraspecific feeding relationships in estuarine fish, Journal of Fish Biology, 51, 526-545.

35. Mikhailova E. S. and Kasumyan A. O., 2010 - Taste preferences and feeding behaviour in Threespine Stickleback Gasterosteus aculeatus in marine and fresh waters, Journal of Ichthyology, 50, 9, 795-807.

36. Milstein A., Naor A., Barki A. and Harpaz S., 2013 - Utilization of periphytic natural food as partial replacement of commercial food in organic Tilapia culture - an overview, Transylvanian Review of Systematical and Ecological Research, The Wetlands Diversity, 15.1, 49-60.

37. Mohan M. V. and Sankaran T. M., 1988 - Two new indices for stomach content analysis of fishes, Journal of Fish Biology, 33, 289-292.

38. Motta P. J. and Kotrschall K. M., 1992 - Correlative, experimental, and comparative evolutionary approaches in ecomorphology, Netherlands Journal of Zoology, 42, 400-415.

39. Nakajima K., Asakura T., Maruyama J., Morita Y., Oike H., Shimizu-ibuka A., Misaka T., Sorimachi H., Arai A., Kitamoto K. and Abe K., 2006 - Extracellular production of a heterodimetric protein, neoculin, with sweet-tasting and taste modifying activities by Aspergillus oryzae, Applied Environmental Microbiology, 72, 3716-3723.

40. Nelson G., Hoon M. A., Chandrasekhar J., Zhang Y., Ryba N. J. P. and Zuker C. S., 2001 Mammalian sweet taste receptors, Cell, 106, 381-390. 
41. Ofori-Danson P. K. and Grace N. K., 2006 - Food and Feeding Habit of Sarotherodon melanotheron, Rüppell, 1852 (Pisces: Cichlidae) in Sakumo Lagoon, Ghana, West African Journal of Applied Ecology, 10, 1, 9-18.

42. Ogunlaru A., Anetekhai M. A., Kumolu-Johnson C. A., Jimoh A. A. and Whenu O. O., 1997 Food, feeding habits and sex ratio of Chana obscura (Gunther) from Era swamps, Ojo Lagos, Nigeria, Journal of Prospects in Science, 1, 70-75.

43. Ohkubo Y., Masubuchi M., Fujioka K., Tomita Y., Matsushita T., Ohsuga K. and Marui T., 2005 - Distribution and morphological features of taste buds in the Zebra fish, Danio rerio, Journal of Oral Bioscience, 47, 1, 77-82.

44. Olden J. D., Poff N. L. and Bestgen K. R., 2006 - Life-history strategies predict fish invasions and extirpations in the Colorado River basin, Ecological Monographs, 76, 1, 25-40.

45. Pearre jr. S., 1982 - Estimation prey preference by predators: uses of various indices, and a proposal of another based on $\chi^{2}$, Canadian Journal of Fisheries and Aquatic Science, 39, 6, 914-923.

46. Pelicice F. M. and Agostinho A. A., 2006 - Feeding ecology of fishes associated with Egeria sps. Patches in a tropical reservoir, Brazil, Ecology of Freshwater Fish, 15, 10-19.

47. Pelicice F. M., Agostinho A. A. and Thomaz S. M., 2005 - Fish assemblages associated Egera in a tropical reservoir: investigating the effects of plant biomass and diel period, Acta Oecologia, 27, 9-16.

48. Pianka E. R., 1973 - The structure of lizard communities, Annual Review of Ecology and Systematics, 4, 53-74.

49. Pinkas L., Oliphant M. S. and Iverson I. L. K., 1971 - Food habits of albacore, bluefin tuna, and bonito in California waters, California Department of Fisheries Game, Fisheries Bulletin, 152, 105.

50. Pothoven S. A. and Nalepa T. F., 2006 - Feeding ecology of lake Whitefish in lake Huron, Journal of Great Lakes Research, 32, 489-501.

51. Ringø E., Strøm E. and Tabachek J. A., 1995 - Intestinal microflora of salmonids: a review, Aquaculture Research, 26, 773-789.

52. Roy T., Mondal S. and Ray A. K., 2009 - Phytase-producing bacteria in the digestive tracts of some freshwater fish, Aquaculture Research, 40, 3, 344-353.

53. Sabapathy U. and Teo L. H., 1993 - A quantitative study of some digestive enzymes in the rabbitfish, and the sea bass, Journal of Fish Biology, 42, 595-602.

54. Saikia S. K., 2012 - Proposal of new and simple descriptive measure of diet breadth, Ecologia, 2, 3, 85-92.

55. Saikia S. K. and Das D. N., 2009 - Feeding ecology of Common carp (Cyprinus carpio L.) in rice fish culture system of Apatani Plateau, India, Aquatic Ecology, 43, 559-568.

56. Saikia S. K., Majumder S., Nandi S. and Saha S. K., 2013 - Feeding ecology of the freshwater fish Rohu Labeo rohita (Hamilton 1822): A case of intelligent feeding in a periphyton-based environment, Zoology and Ecology, 23, 4, 266-274.

57. Schoener T. W., 1970 - Non synchronous spatial overlap of lizards in patchy habitats, Ecology, 51, 408-418.

58. Sherwood A. R. and Nishimoto R. T., 2005 - Algal food preferences of the endemic Hawaiian stream goby Sicyopterus stimpsoni (Teleostei: Gobiidae), Ichthyological Exploration of Freshwaters, 16, 2, 97-106.

59. Strauss R. E. and Bookstein F. L., 1982 - The TRUSS: Body form reconstruction in morphometrices, Systematic Zoology, 31, 2, 113-135.

60. Teixeira I. and Bennemann S. T., 2007 - Ecomorfologia refletindo a dieta dos peixes em um reservatório no sul do Brasil, Biota Neotropica, 7, 2, 67-76. (in Spanish)

61. Vonk H. J. and Western J. R. H., 1984 - Comparative biochemistry and physiology of enzymatic digestion, London: Academic Press.

62. Zhao G. Q., Zhang Y., Hoon M. A., Chandrasekhar J., Erlenbach I., Ryba N. J. P. and Zuker C. S., 2003 - The receptor for mammalian sweet and umami taste, Cell, 115, 255-266. 